\title{
INCIDENCE OF HAEMOLYTIC ANAEMIA IN A TERTIARY CARE CENTRE IN CENTRAL KERALA, INDIA
}

\author{
Sunitha Balakrishnan'1, P. S. Jayalakshmy2, Meenu Venukumar ${ }^{3}$
}

${ }^{1}$ Associate Professor, Department of Pathology, Government Medical College, Thrissur.

${ }^{2}$ Additonal Professor, Department of Pathology, Government Medical College, Thrissur.

3Junior Resident, Department of Pathology, Government Medical College, Thrissur.

\begin{abstract}
\section{BACKGROUND}

Haemolytic anaemias can be classified as intrinsic, where the cause is related to the defect in red cells or extrinsic, where factors external to the RBC cause red cell destruction. In intrinsic type the abnormality is in the RBC membrane, enzyme or haemoglobin, whereas in extrinsic type the abnormality is immune mediated due to toxins or direct trauma. They can also be classified as inherited haemolytic anaemias and acquired haemolytic anaemia. The present study was carried out to assess the magnitude of different types of haemolytic anaemias diagnosed in a tertiary care centre in central part of Kerala, India.
\end{abstract}

\section{MATERIALS AND METHODS}

The study was conducted in the Department of Pathology, Government Medical College, Thrissur, for a period of 3 years from 0109-2012 to 31-08-2015. All the clinically suspected cases of haemolytic anaemias, i.e. cases with anaemia and jaundice were considered; the cases without definitive diagnosis were excluded from the study.

\section{RESULTS}

Total of 114 haemolytic anaemia cases were studied, of which $51.75 \%$ (59 cases) were females and $48.24 \%$ (55 cases) were males. Hereditary haemolytic anaemia accounted for $74.56 \%$ (85 cases) and acquired haemolytic anaemia were $25.43 \%$ (29 cases). The patients were in the age group of 3 days (new born) to 70 years.

\section{DISCUSSION}

Of the 114 cases, sickle cell disease was the commonest followed by microangiopathic haemolytic anaemia. The other hereditary haemolytic anaemia in this study included thalassemia, sickle-thal, Hb E disease, Hb E - $\beta$ Thal, hereditary spherocytosis, G6PD deficiency and porphyria. Acquired haemolytic anaemia include immune haemolytic anaemia, microangiopathic haemolytic anaemia and drug-induced haemolysis.

\section{CONCLUSION}

The study is mainly done to assess the magnitude of haemolytic anaemia and the different aetiological factors. It also reveals the importance of additional investigations, which help considerably to find out the cause.

\section{KEYWORDS}

Sickle Cell Anaemia, Microangiopathic Haemolytic Anaemia, Immune Haemolytic Anaemia.

HOW TO CITE THIS ARTICLE: Balakrishnan S, Jayalakshmy PS, Venukumar M. Incidence of haemolytic anaemia in a tertiary care centre in central Kerala, India. J. Evolution Med. Dent. Sci. 2016;5(80):5969-5973, DOI: 10.14260/jemds/2016/1348

\section{BACKGROUND}

The normal lifespan of RBCs is $90-120$ days. Increased red cell destruction results in haemolysis and the patient present with anaemia. There are many types of haemolytic anaemia, which may be classified according to the means of haemolysis. That can be either intrinsic where the cause is related to the Red Blood Cell (RBC) itself or extrinsic where factors external to the RBC cause destruction.[1] In intrinsic type the abnormality is in the RBC membrane, enzyme or haemoglobin whereas in the extrinsic type the abnormality is immune mediated due to toxins or direct trauma.[1,2]

They can also be classified as inherited haemolytic anaemia and acquired haemolytic anaemias.[3,4]

Financial or Other, Competing Interest: None.

Submission 29-05-2016, Peer Review 24-09-2016,

Acceptance 30-09-2016, Published 05-10-2016.

Corresponding Author:

Dr. Sunitha Balakrishnan,

Associate Professor in Pathology,

Government Medical College, Thrissur, Kerala.

E-mail: sunithaharibala@gmail.com

DOI: $10.14260 /$ jemds $/ 2016 / 1348$
In inherited haemolytic anaemia, one or more of the genes that control red blood cell production are faulty. This can lead to abnormalities with the haemoglobin, cell membrane or enzymes that maintain healthy red blood cells.[2,5] The abnormal cells may be fragile and break down while moving through the bloodstream. Inherited haemolytic anaemia include sickle cell anaemia, thalassemia, hereditary spherocytosis, hereditary elliptocytosis, G6PD deficiency, pyruvate kinase deficiency, etc.[3,6]

In acquired haemolytic anaemia, red blood cells may be normal but some other disease or factors destroy red blood cells and remove them from the bloodstream. The destruction of the red blood cells occur in the bloodstream or more commonly in the spleen.[2,3] Acquired haemolytic anaemias include immune haemolytic anaemia, drug-induced haemolytic anaemia, microangiopathic haemolytic anaemia, PNH and infections like malaria and Leishmaniasis, snake venom, toxic chemicals, etc.[3]

Both hereditary and immune haemolytic anaemias have been studied individually and reported from various parts of India, but the haematological profile in haemolytic anaemias in general affecting all age groups are rarely reported. The 
present study was carried out to assess the magnitude of a variety of haemolytic anaemias diagnosed in a tertiary care centre in central part of Kerala.. ${ }^{[3,7]}$

\section{MATERIALS AND METHODS}

The study was conducted in the Department of Pathology, Government Medical College, Thrissur, for a period of 3 years from 01-09-2012 to 31-08-2015. All the clinically suspected cases of haemolytic anaemias, i.e. cases with anaemia and jaundice were considered, but the cases without definitive diagnosis were excluded from the study.

A total of 114 cases belonging to different aetiologies and all age groups were studied. This included 59 females and 55 males. The cases were subjected to routine and special investigations.

These Include

- Complete blood count (Sysmex 5-part cell counter).

- Peripheral smear examination (Leishman stain).

- Reticulocyte count (Brilliant cresyl blue, 1\%).

- Osmotic fragility test.

- $\quad$ Sickling test (using $2 \%$ Sodium metabisulphite as reducing agent).

- Serum bilirubin.

- Direct Coombs test.

- Hb electrophoresis (in some cases).

- $\quad$ High Performance Liquid Chromatography - HPLC (in some cases).

\section{RESULTS}

Total of 114 haemolytic anaemia cases were studied, of which $51.75 \%$ (59 cases) were females and $48.24 \%$ (55 cases) were males [Fig. 1]. Hereditary haemolytic anaemia accounted $74.56 \%$ (85 cases) and acquired haemolytic anaemia were $25.43 \%$ (29 cases) [Fig. 2]. The patients were in the age group of 3 days (new born) to 70 years [Fig. 3].

\begin{tabular}{|c|l|c|}
\hline Sl. No. & Type of Haemolytic Anaemia & Percentage \\
\hline 1 & Sickle cell disease & $38.6 \%$ \\
\hline 2 & Thalassemia & $10.5 \%$ \\
\hline 3 & Sickle-thal & $5.3 \%$ \\
\hline 4 & Hb E disease & $2.6 \%$ \\
\hline 5 & Hb E-Beta thal & $0.8 \%$ \\
\hline 6 & Hereditary spherocytosis & $10.5 \%$ \\
\hline 7 & G6PD deficiency & $5.3 \%$ \\
\hline 8 & $\begin{array}{l}\text { Microangiopathic haemolytic } \\
\text { anaemia }\end{array}$ & $11.40 \%$ \\
\hline 9 & Haemolytic disease of newborn & $0.8 \%$ \\
\hline 10 & Autoimmune haemolytic anaemia & $7.9 \%$ \\
\hline 11 & Porphyria & $0.8 \%$ \\
\hline 12 & $\begin{array}{l}\text { Drugs/chemicals induced } \\
\text { haemolytic anaemia }\end{array}$ & $3.5 \%$ \\
\hline 13 & Spur cell anaemia & $1.8 \%$ \\
\hline \multicolumn{2}{|c|}{ Table 1: Percentage of Haemolytic Anaemia Cases } \\
& \multicolumn{2}{|c|}{ in this Series } \\
\hline
\end{tabular}

All the cases in the study were properly clinically correlated. All were found to have hyperbilirubinaemia. All the cases positive for sickling test [Fig. 4] were diagnosed as sickle cell disease. Those with sickle cells in the peripheral smear were diagnosed as sickle cell anaemia [Fig. 5]. The cases with positive sickling test and peripheral smear showing microcytic hypochromic anaemia with scattered target cells were advised to do $\mathrm{Hb}$ electrophoresis/HPLC to confirm Sickle-thal. Those with negative sickling test and peripheral smear showing microcytic hypochromic anaemia and target cells with normal RDW are also advised to do $\mathrm{Hb}$ electrophoresis/HPLC to confirm other hereditary haemolytic anaemia like thalassemia [Fig. 6, 7], $\mathrm{Hb} \mathrm{E,} \mathrm{Hb} \mathrm{E-thal} \mathrm{[Fig.} \mathrm{8,} \mathrm{9]} \mathrm{etc.} \mathrm{Microangiopathic}$ Haemolytic Anaemias (MAHA) showed evidence of haemolysis and fragmented RBCs and spherocytes [Fig. 10]. G6PD deficiency was associated with drugs, mainly dapsone. Peripheral smear showed bite cells and blister cells [Fig. 11] and Heinz body could be demonstrated. All immune haemolytic anaemias were positive for Direct Coombs Test. All spherocytic haemolytic anaemias in young individuals with splenomegaly were further investigated with osmotic fragility test and family screening. All hereditary spherocytosis cases showed increased osmotic fragility.

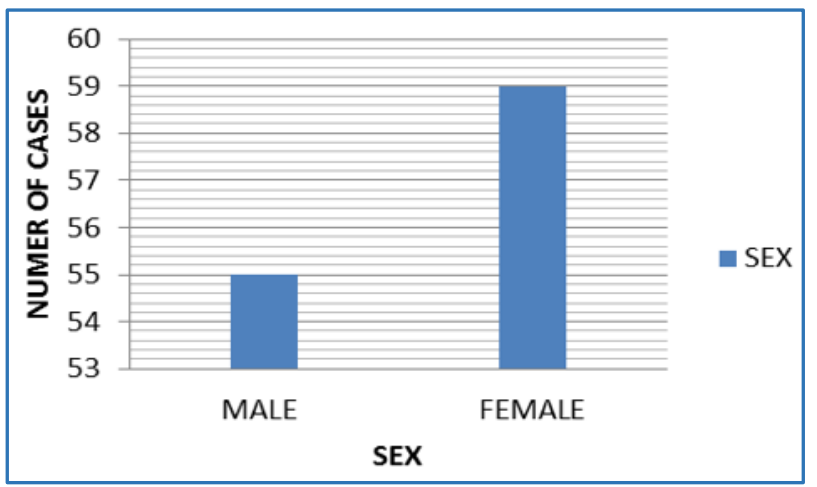

Fig. 1: Sex Distribution of Haemolytic Anaemia

\section{TYPE OF HEMOLYTIC ANAEMIA}

\section{- HEREDITARY a ACQUIRED}

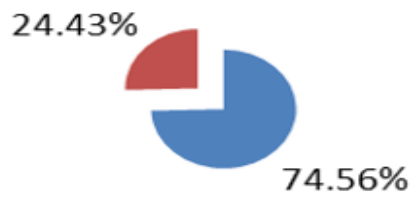

Fig. 2: Type of Haemolytic Anaemia

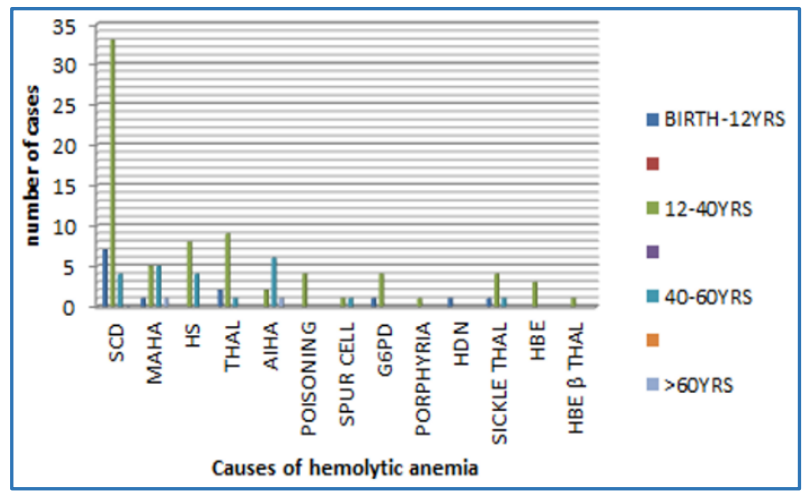

Fig. 3: The Age Distribution 


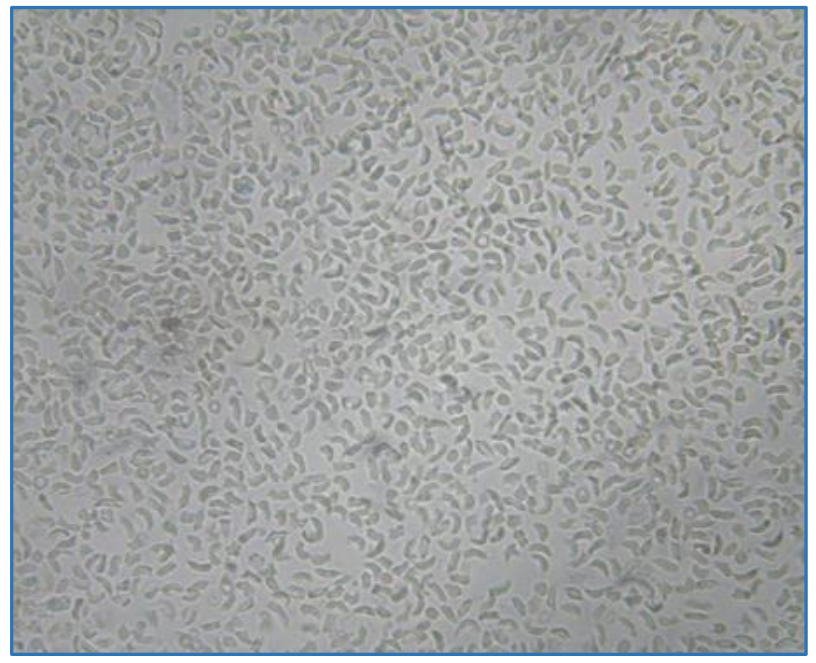

Fig. 4: Positive Sickling Test [Leishman X 1000]

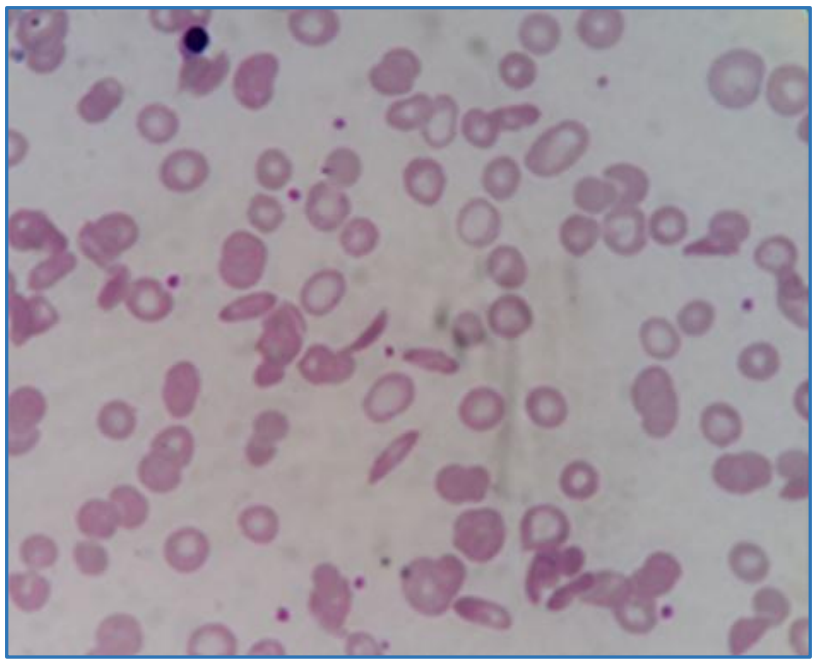

Fig. 5: Sickle Cell Anaemia [Leishman X 1000]

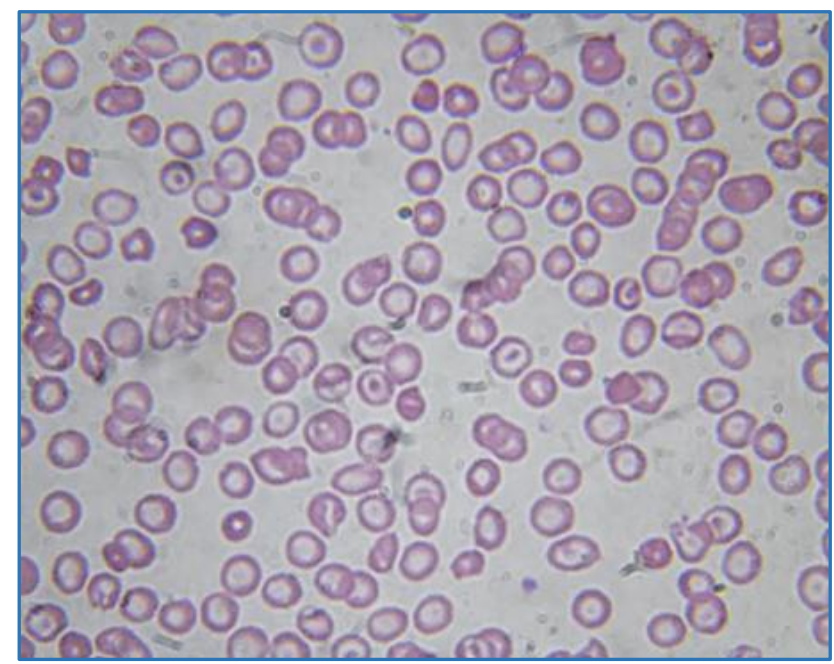

Fig. 6: Thalassemia - Minor [Leishman X 1000]

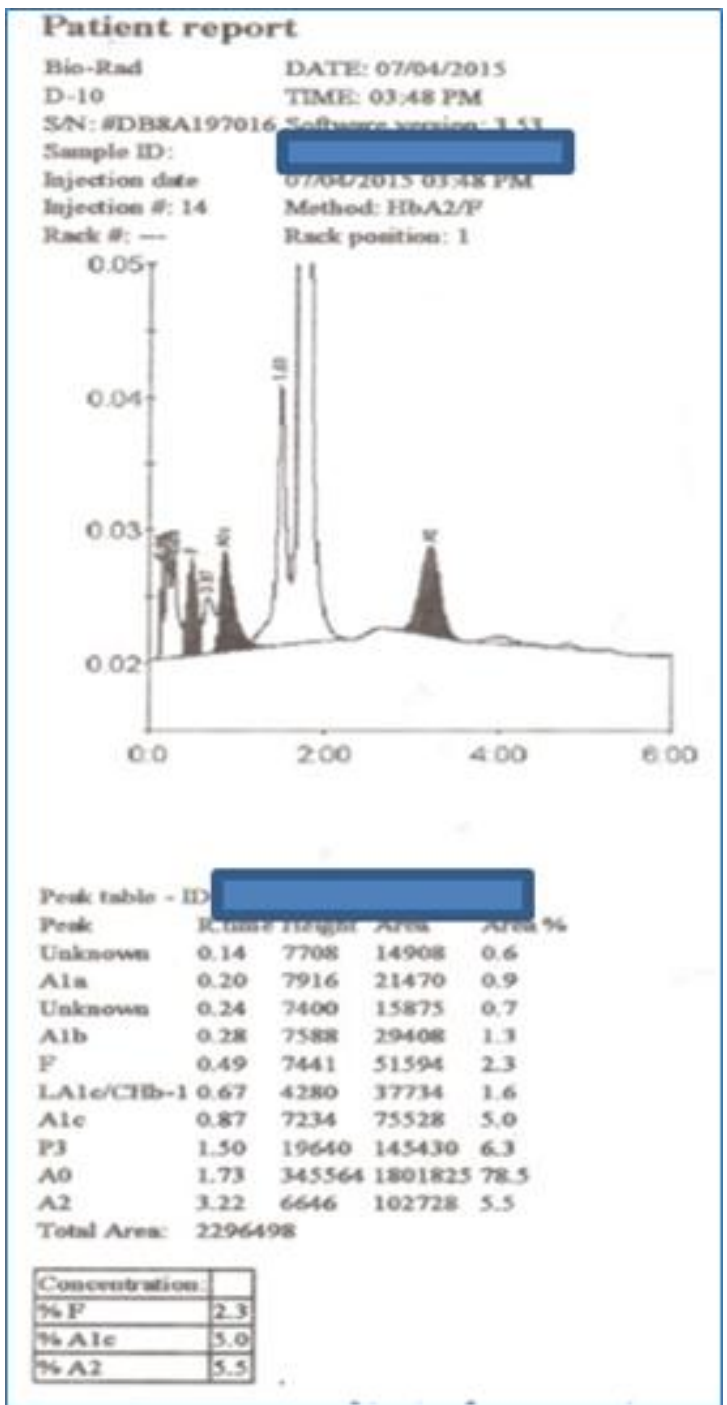

Fig. 7: HPLC - Thal-Minor

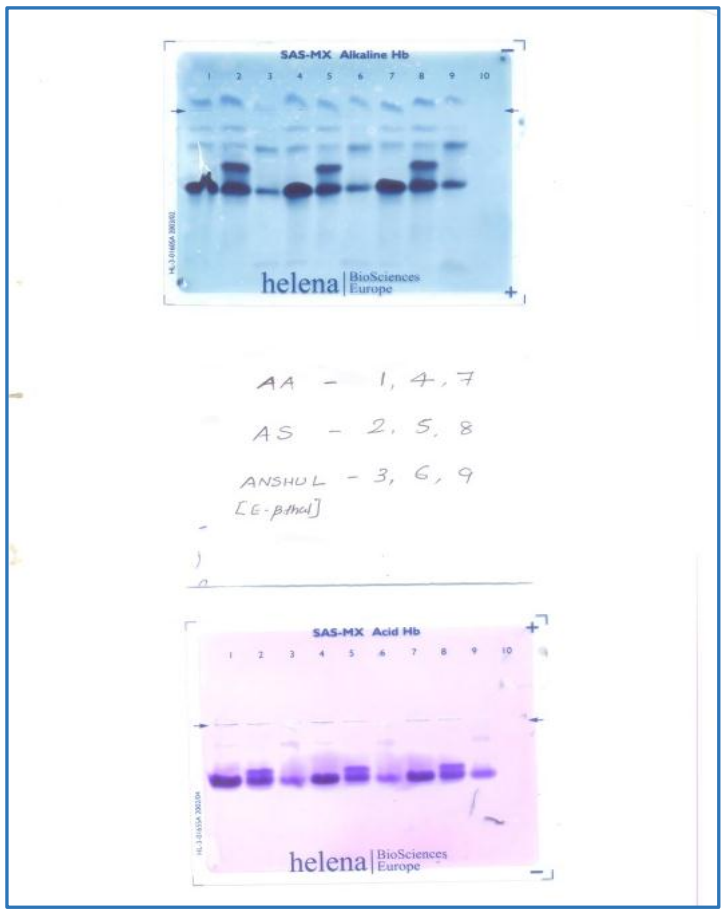

Fig. 8: Hb Electrophoresis Hb E $\beta$ Thal 


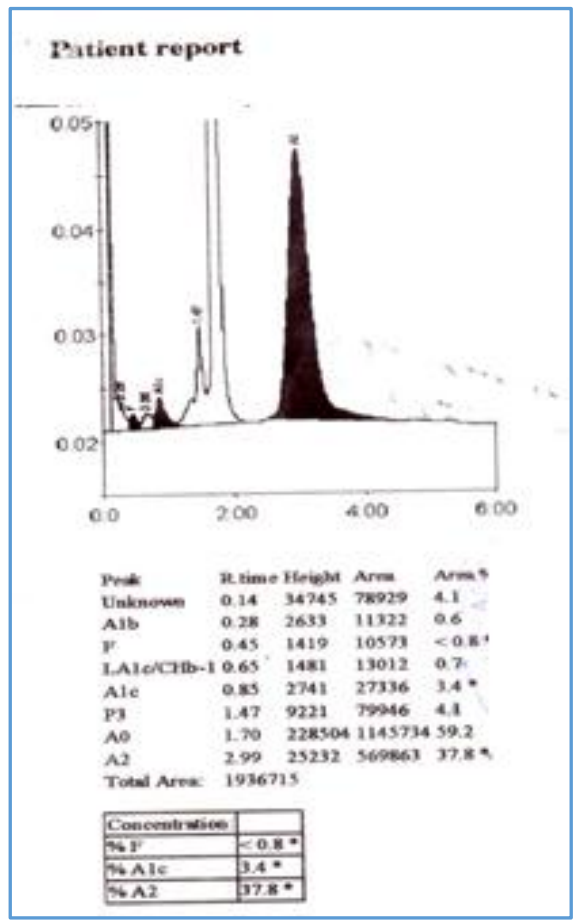

Fig. 9: HPLC - Hb E-Beta Thal

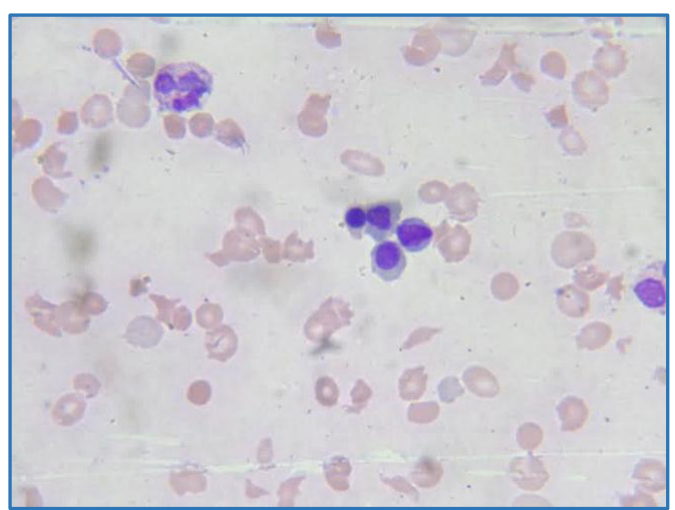

Fig. 10: MAHA - Leishman X 1000

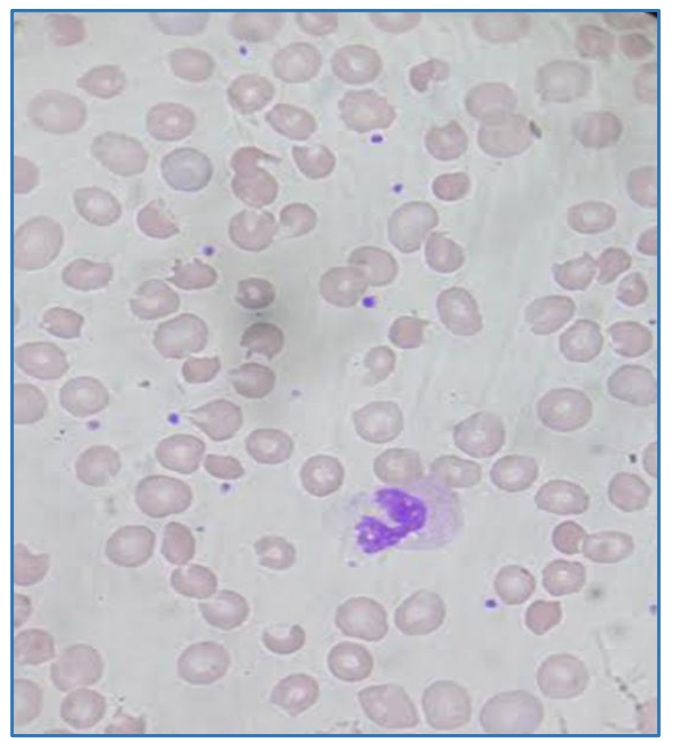

Fig. 11: G6PD Deficiency - Leishman X 1000 anaemias which accounted for $74.6 \%$. Acquired haemolytic anaemias were 29 , which accounted for $25.43 \%$. In the hereditary haemolytic anaemias, commonest was sickle cell disease (38.6\%) [Table 1]. Sickle cell disease is one of the most common monogenic disorders globally with autosomal recessive inheritance. In the study conducted by Giri et al at Baroda (Gujrat) in 1984, there were 51 cases of haemolytic anaemia in which beta thalassemia major was leading cause with 29 cases and sickle cell anaemia was $2^{\text {nd }}$ with 15 cases. ${ }^{[7]}$ The increase in the number of sickle cell disease in the study may be due to the increased prevalence of the disease among the tribal population in Attappadi, Palakkad District, which is the neighbouring district of Thrissur. ${ }^{[8]}$ Another cause may be the increased number of migrant worker population from the North East States of India, i.e. Odisha, Bihar and West Bengal where sickle cell disease is prevalent. $[9,10]$

In our study, 6 cases (5.3\%) showed associated thalassemia component along with sickle cell disease which was proved by either Hb electrophoresis or HPLC. Roshan et al from Odisha showed the presence of HbS- $\beta$ thalassemia.[11] In Kerala also, there are studies showing increased incidence of $\mathrm{HbS}-\beta$ thalassemia. All the three $\mathrm{Hb}$ E disease and one $\mathrm{Hb} \mathrm{E}-\beta$ thal were from the migrant worker population. $\mathrm{Hb} \mathrm{E}$ is widely distributed in the North Eastern states.[11]

In our study, there were 6 cases (5.3\%) of G6PD deficiency. All of them showed the classical bite cells and blister cells in the peripheral smear. One among those was a newborn with very low levels of G6PD.[12] Another case was that of a migrant from Odisha with associated $\mathrm{Hb} \mathrm{E}-\beta$ thalassemia. He had severe haemolysis due to the oxidant stress. The rest of the cases were drug induced. Padmasree et al in their study show that it is mainly produced by antimalarial drugs, but all our cases were dapsone induced while on treatment for leprosy.

In the present study, Microangiopathic Haemolytic Anaemia (MAHA) was the second commonest haemolytic anaemia $(11.4 \%)$. The disease had a variety of causes. Predominant cause was haemolytic uremic syndrome. Patients were children presenting in acute renal failure. The other causes included Disseminated Intravascular Coagulation as a sequel to infections like chicken pox, pneumonia, HELLP syndrome and snake bite.

We also had a rare case of late onset congenital erythropoietic porphyria. It was a 41-year-old female who presented at the age of 20 with hyper and hypopigmentation of skin and sclerodactyly. She had brownish discoloration of teeth, which showed red fluorescence in UV light and her urine also showed reddish pink fluorescence in UV light. Her peripheral smear showed evidence of haemolysis. To the best of our knowledge, only 17 cases of late onset congenital erythropoietic porphyria have been reported till date ${ }^{[13,14]}$ in the literature.

\section{CONCLUSION}

In the present study conducted in a tertiary care hospital, there were 114 proven cases of haemolytic anaemia over a period of 3 years with a variety of causes and involving all age groups. The study is mainly done to assess the magnitude of haemolytic anaemia and the different aetiological factors. Additional investigations has to be done, which help considerably to find out the cause.

\section{DISCUSSION}

In the present study there were 114 proven cases of haemolytic anaemia; 85 cases were hereditary haemolytic 


\section{REFERENCES}

1. J,Anil."Haemoglobinopathy in childhood".MD. Marathwada University, Aurangabad.1986.

2. McPhee SJ, Maxine A. Current medical diagnosis and treatment 2009. 48 ${ }^{\text {th }}$ edn. McGraw-Hill Lange 2009:p. 436.

3. Shah A. Acquired hemolytic anemia. Indian J Med Sci 2004;58(12):533-6.

4. Greer JP, Arber DA, Glader B, et al. Wintrobes clinical hematology. $13^{\text {th }}$ edn. Philadelphia: Lippincott Williams \& Wilkins 2014:707-822.

5. Bosman GJ, Willekens FL, Werre JM. Erythrocyte aging: a more than superficial resemblance to apoptosis? Cell Physiol Biochem 2005;16(1-3):1-8.

6. Hillman RS, Ault KA, Rinder HM. Hematology in clinical practice: a guide to diagnosis and management. $5^{\text {th }}$ edn.2005. Mc Graw-Hill education, Newyork ;136-139.

7. Deshpande RH, Joshi AR. Hematological profile in hemolytic anemia. Al Ameen J Med Sci 2012;5(2):191-6.

8. Feroze M, Aravindan KP. Sickle cell disease among the tribals in Attappady. www.cds.ac.in/krpcds/report/feroz.pdf

9. Kaur M, Das GP, Verma IC. Sickle cell trait and disease among tribal communities in Orissa, Madhya pradesh and Kerala. Indian J Med Res 1997;105:111-16.
10. Colah RB, Mukharjee MB, Martin S, et al. Sickle cell disease in tribal populations in India Indian. J Med Res 2015;141:509-515.

11. Mohanty D, Mukharjee MB, Colah RB, et al. Spectrum of hemoglobinopathies among the primitive tribes: a multicentric study in India. Asia Pac J Public Health 2015;27(2):NP562-71.

12. Dantu P, Pusuluri S, Ukey UU. Drug induced hemolytic anemia and G6PD variants in Malaria. International Journal of Basic and applied Medical Sciences 2103;3(2):46-50.

13. Majid S, Ahmad QM, Hassan I, et al. Puberty onset congenital erythropoietic porphyria - a case report. Journal of Regional Section of Serbian Medical Association in Zajecar 2006;31(4):176-9.

14. Bratosin D, Mazurier J, Tissier JP, et al. Cellular and molecular mechanisms of senescent erythrocyte phagocytosis by macrophages: a review. Biochimie 1998;80(2):173-95. 